\title{
PEMBENTUKAN KELOMPOK IBU SIAGA STUNTING DALAM PEMULIHAN BALITA GIZI BURUK MENGGUNAKAN PROGRAM ISI PIRINGKU
}

\author{
Nora Rahmanindar ${ }^{1)}$, Evi Zulfiana ${ }^{2)}$, Riska Arsita Harnawati ${ }^{3)}$ \\ Program Studi DIII Kebidanan Politeknik Harapan Bersama
}

\begin{abstract}
Abstrak
Setiap orang harus makan-makanan yang beranekaragam dan memenuhi syarat gizi. Menurut panduan umum gizi seimbang (PUGS) susunan hidangan harus ada dan wajib terdiri dari nasi, lauk, sayur serta buah-buahan yang meliputi makanan pokok sebagai unsur sumber energi, lauk sebagai unsur sumber protein dan lemak, sayuran dan buah sebagai unsur sumber mineral dan vitamin. Buah dan sayur merupakan unsur sumber pangan yang kaya akan vitamin dan mineral yang sangat bermanfaat untuk kesehatan, perkembangan, dan pertumbuhan tubuh kita. Puskesmas Bumijawa merupakan puskesmas yang terletak di Kabupaten Tegal, wilayah dataran tinggi. Prevalensi kasus gizi buruk di Puskesmas Bumijawa 2,5\%, balita stunting 6,09\%, balita gizi kurang 4,1\% dan gizi buruk dibawah 2SD sebanyak $0,9 \%$. Stunting adalah masalah kurang gizi kronis yang disebabkan oleh kurangnya asupan gizi dalam waktu yang cukup lama, sehingga mengakibatkan gangguan pertumbuhan pada anak yakni tinggi badan anak lebih rendah atau pendek (kerdil) dari standar usianya Tujuan dari pengabdian ini adalah pembentukan kelompok ibu siaga stunting dan meningkatkan pengetahuan ibu tentang pengertian stnting, dampak dan cara pencegahan stunting dan gizi buruk dengan program isi piringku.
\end{abstract}

Kata Kunci : Isi piringku, Stunting.

\begin{abstract}
Everyone must eat a variety of foods and meet nutritional requirements. According to general guidelines for balanced nutrition (PUGS) the composition of dishes must consist of rice, side dishes, vegetables and fruits which are naturally very high in value, namely staple food as a source of energy, side dishes as a source of protein and fat, vegetables and fruit as a source of minerals and vitamins. Fruits and vegetables are rich food sources of vitamins and minerals that are very beneficial for health, development, and growth. Puskesmas Bumijawa is a puskesmas located in Tegal Regency, a highland area. The prevalence of malnutrition cases at the Bumijawa Health Center was 2.5\%, stunting toddlers $6.09 \%$, underfives malnutrition $4.1 \%$ and malnutrition under -2 SD as much as $0.9 \%$. Stunting is a chronic malnutrition problem caused by lack of nutritional intake for a long time, resulting in growth problems in children, namely the child's height is lower or shorter (stunted) than the standard age. The purpose of this dedication is the establishment of a group of stunting standby mothers and increasing the mother's knowledge about understanding stnting, the impact and ways of preventing stunting and malnutrition with my plate contents program.
\end{abstract}

Keywords: Fill my plate, Stunting.

Correspondence author: Nora Rahmanindar, norarahmanindar@gmail.com Tegal, Indonesia

This work is licensed under a $C C-B Y-N C$ 


\section{PENDAHULUAN}

Stunting adalah masalah akibat dari kurang nya gizi kronis yang disebabkan oleh karena kurang asupan gizi yang dalam waktu cukup lama, sehingga mengakibatkan gangguan pertumbuhan pada anak yaitu tinggi badan anak lebih rendah atau pendek (kerdil) dari standar usianya. ${ }^{1}$ Salah satu fokus pemerintah saat ini yaitu pencegahan stunting. Upaya ini bertujuan supaya generasi penerus bangsadi Indonesia dapat tumbuh dan berkembang secara optimal serta maksimal, disertai kemampuan emosional, sosial, dan fisik yang siap untuk belajar, dan mampu berinovasi, berkompetisi di tingkat global. Stunting dapat terjadi sebagai akibat kurangnya gizi pada saat 1000 Hari Pertama Kehidupan (HPK). Salah satu cara untuk pencegahan stunting yaitu dengan pemenuhan gizi serta layanan fasilitas kesehatan pada ibu hamil. Upaya ini penting dilakukan, mengingat stunting karena berpengaruh terhadap tingkat kecerdasan anak dan status kesehatan pada saat dewasa. Akibatnya jika kekurangan gizi pada 1000 HPK ini akan bersifat permanen dan susah diperbaiki. Penyebab utama dari anak stunting adalah asupan gizi. Terdapat tiga hal yang harus diperhatikan dalam pencegahan stunting, yaitu perbaikan terhadap pola makan, pola asuh, serta perbaikan sanitasi dan akses air bersih. ${ }^{2}$

Pola Makan, Masalah stunting dipengaruhi oleh rendahnya pengetahuan orang tua untuk mendapatkan akses terhadap makanan dari segi jumlah dan kualitas gizi, serta seringkali tidak beragam. Istilah "Isi Piringku" dengan gizi seimbang perlu diperkenalkan dan dibiasakan dalam kehidupan sehari-hari. Dalam satu porsi makan terdiri dari, setengah piring diisi oleh sayur dan buah, setengahnya diisi dengan sumber protein (baik nabati maupun hewani) dengan proporsi lebih banyak daripada karbohidrat. $^{2}$

Pola Asuh, Stunting juga dipengaruhi oleh aspek perilaku, terutama pola asuh yang kurang baik dalam praktik pemberian makan bagi bayi dan Balita. Dimulai dari para calon ibu dengan pemberian edukasi tentang kesehatan reproduksi, gizi bagi remaja, hingga para calon ibu memahami pentingnya memenuhi kebutuhan gizi saat hamil dan stimulasi bagi janin, serta memeriksakan kandungan empat kali selama kehamilan. Ibu yang bersalin di fasilitas kesehatan, segera mungkin bayinya untuk dilakukan inisiasi menyusu dini (IMD) agar bayi mendapat colostrum air susu ibu (ASI). Menganjurkan ibu untuk memberikan hanya ASI saja sampai bayi berusia 6 bulan. Setelah itu, ASI boleh dilanjutkan sampai usia 2 tahun, dan memberikan makanan pendamping ASI. Pantau tumbuh kembang balita dan imunisasi sesuai dengan jadwal dengan membawa ke Posyandu setiap bulan. ${ }^{2}$

Sanitasi dan Akses Air Bersih, masih rendahnya cakupan akses terhadap pelayanan kesehatan, termasuk diantaranya akses sanitasi dan air bersih, mendekatkan anak-anak pada risiko ancaman terhadap penyakit infeksi, menerapkanpola hidup bersih dan sehat perlu membiasakan cuci tangan pakai sabun dan air mengalir, serta tidak buang air besar sembarangan. "Pola asuh dan status gizi dipengaruhi oleh pemahaman dan pengetahuan dari orang tua (seorang ibu) agar bisa mengatur kesehatan dan gizi di keluarganya. Edukasi sangat diperlukan agar bisa mengubah perilaku yang bisa mengarahkan pada peningkatan kesehatan gizi atau ibu dan anaknya". Porsi Isi Piringku yang dianjurkan oleh Kementerian Kesehatan yaitu Makanan pokok (sumber kabohidrat) dengan porsi dua per tiga dari setengah piring. Lauk pauk (sumber protein) dengan porsi sepertiga dari setengah piring. Sayur-sayuran (sumber vitamin dan 
mineral) dengan porsi dua per tiga dari setengah piring dan buah-buahan (sumber vitamin dan mineral) dengan porsi sepertiga dari setengah piring. ${ }^{2,3,4}$

Puskesmas Bumijawa merupakan puskesmas yang terletak di Kabupaten Tegal, wilayahnya dataran tinggi. Prevalensi kasus gizi buruk di Puskesmas Bumijawa 2,5\%, balita stunting 6,09\%, balita gizi kurang 4,1\% dan gizi buruk dibawah -2SD sebanyak 0,9\%. Di wilayah Puskesmas Bumijawa ibu-ibu yang mempunyai balita gizi buruk belum mengerti tentang asupan pola makan, pola asuh untuk bayi, bayi-bayi sudah diberi Makanan Pendamping ASI sebelum usia bayi 6 bulan, tidak menjaga perilaku hidup bersih dan sehat.

Program gizi di wilayah Puskesmas Bumijawa dilakukan dengan pendekatan yang menyeluruh, seperti melakukan pendataan posyandu-posyandu dan pemberian penyuluhan kesehatan berkaitan dengan pengetahuan tentang gizi anak, mulai dari pemberian makanan apa saja yang boleh diberikan untuk bayi di atas enam bulan, bagaimana tekstur yang baik, berapa banyak porsi yang harus diberikan, termasuk pengetahuan pentingnya ASI eksklusif. ${ }^{2}$

Sehubungan dengan hal tersebut maka diperlukan pembentukan Kelompok Ibu Siaga Stunting Dalam Pemulihan Balita Gizi Buruk Menggunakan Program Isi Piringku Di Wilayah Puskesmas Bumijawa agar dapat mengurangi kejadian Stunting dan balita gizi buruk pada balita. Berdasarkan hal tersebut kami akan melakukan pembentukan kelompok ibu siaga stunting dan pendidikan kesehatan guna meningkatkan pengetahuan tentang stunting dan gizi buruk pada balita.

Tujuan dari pengabdian ini adalah pembentukan kelompok ibu siaga stunting dan meningkatkan pengetahuan ibu tentang pengertian stnting, dampak dan cara pencegahan stunting dan gizi buruk dengan program isi piringku. Manfaat pengabdian ini adalah Diharapkan dengan adanya kegiatan pembentukan Kelompok Ibu Siaga Stunting Dalam Pemulihan Balita Gizi Buruk Menggunakan Program Isi Piringku Di Wilayah Puskesmas Bumijawa dapat membantu ibu yang mempunyai anak balita untuk selalu menjaga kesehatan dan menjagai asupan gizi yang seimbang pada balita.

\section{METODE PELAKSANAAN}

Kegiatan pengabdian kepada masyarakat mengenai Pembentukan Kelompok Ibu Siaga Stunting Dalam Pemulihan Balita Gizi Buruk Menggunakan Program Isi Piringku di Puskesmas Bumijawa.

Proses pelaksanaan kegiatan pengabdian melalui beberapa tahap yaitu:

1. Ijin kegiatan ke kepala Puskesmas Bumijawa

2. Kontrak waktu dengan bagian gizi Puskesmas Bumijawa

3. Pendataan jumlah ibu yang mempunyai balita stunting dan gizi buruk di puskesmas Bumijawa

4. Mengumpulkan peserta, tamu undangan sebanyak 40 orang.

5. Melakukan pembentukan kelompok ibu siaga stunting dan gizi buruk

Pembentukan Kelompok Ibu Siaga Stunting Dalam Pemulihan Balita Gizi Buruk Menggunakan Program Isi Piringku di Puskesmas Bumijawa dilakukan dengan cara pembentukan kelompok ibu siaga stunting dan gizi buruk dan memberikan penyuluhan pendidikan kesehatan tentang asupan pola makan dengan program isi piringku, pola asuh, ASI Ekslusif, perilaku hidup bersih dengan menggunakan power point dan ibu 
dibagikan materi tentang penyuluhan tersebut, kegiatan dilakukan selama 2 hari yaitu pada hari Rabu dan Kamis tanggal 18-19 Desember 2019 yang bertempat di Puskesmas Bumijawa

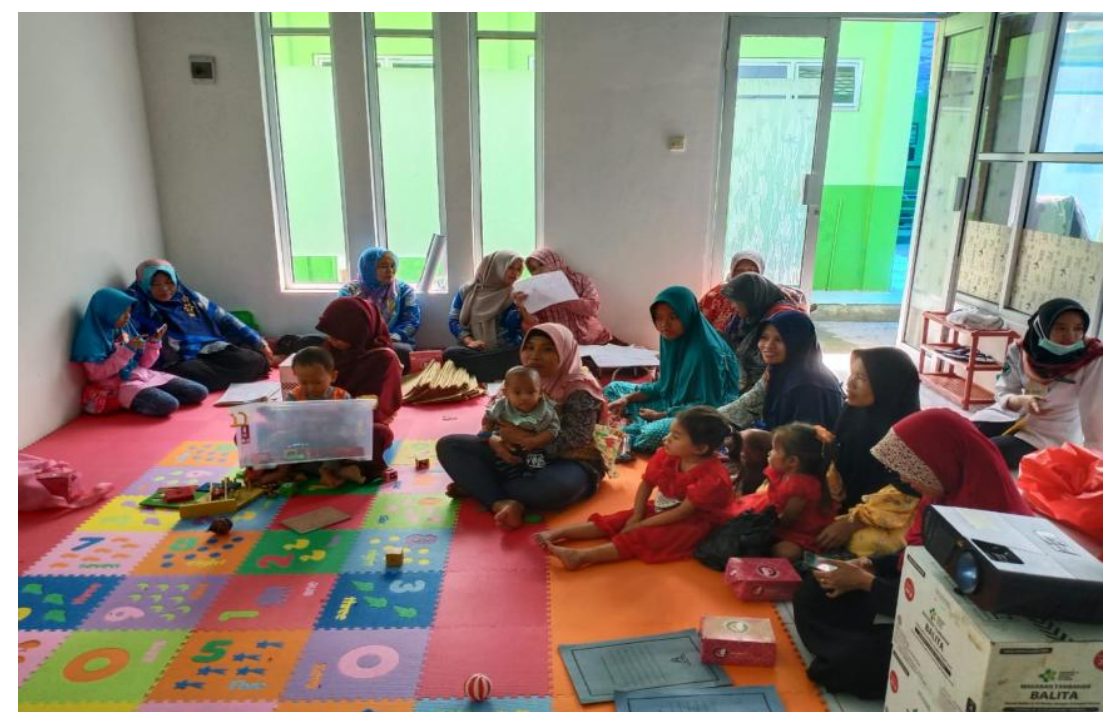

Gambar 1 Kegiatan Penyuluhan pada ibu

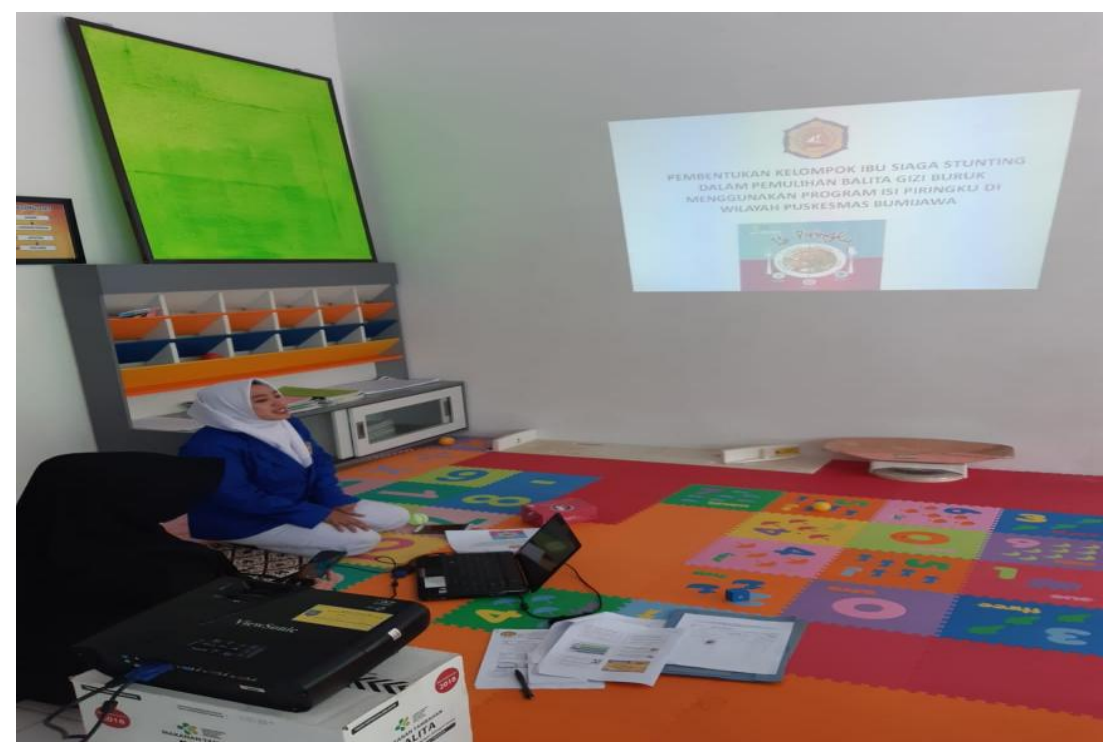

Gambar 2 Kegiatan Pemberian Penyuluhan

\section{HASIL DAN PEMBAHASAN}

Kegiatan pengabdian masyarakat mengenai Pembentukan Kelompok Ibu Siaga Stunting Dalam Pemulihan Balita Gizi Buruk Menggunakan Program Isi Piringku di Puskesmas Bumijawa dilaksanakan 2 hari.

Hasil pelaksanaan kegiatan pengabdian melalui beberapa tahapan yaitu:

1. Ijin kegiatan ke kepala Puskesmas Bumijawa

2. Kontrak waktu dengan bagian gizi 
3. Pendataan jumlah ibu yang mempunyai balita stunting di puskesmas Bumijawa

4. Mengumpulkan peserta sebanyak 40 orang.

5. Melakukan pembentukan kelompok ibu siaga stunting dan gizi buruk

Pelaksanaan kegiatan pengabdian kepada masyarakat di Puskesmas Bumijawa tanggal 18-19 Desember 2019 meliputi kegiatan seperti dibawah ini yaitu:

1. Pretest

Pretest dilakukan untuk memperoleh tingkat pengetahuan ibu tentang asupan pola makan program isi piringku, pola asuh, ASI Ekslusif, perilaku hidup bersih.

2. Penyuluhan

Penyuluhan dilakukan untuk lebih meningkatkan pengetahuan ibu yang mempunyai anak balita stunting dan gizi buruk di Puskesmas Bumijawa. Adapun materi penyuluhan yang disampaikan meliputi review asupan pola makan program isi piringku, pola asuh, ASI Ekslusif, perilaku hidup bersih.

3. Posttest

Posttest dilakukan untuk mengevaluasi kegiatan penyuluhan yang diberikan pada ibu yang mempunyai anak balita stunting dan gizi buruk di Puskesmas Bumijawa.

Sebagian besar ibu yang mempunyai anak balita memiliki tingkat pengetahuan tentang asupan pola makan program isi piringku, pola asuh, ASI Ekslusif, perilaku hidup bersih masih kurang, Setelah diberikan pendidikan kesehatan oleh pemateri terlihat adanya peningkatan pemahaman oleh ibu yang mempunyai anak balita tentang asupan pola makan program isi piringku, pola asuh, ASI Ekslusif, perilaku hidup bersih, selain itu ibu juga sudah mengerti tentang cara menyusun menu makanan menggunakan isi piringku, merawat anak, pemberian ASI Ekslusif dan cara mencuci tangan.

Tabel 1. Peningkatan pengetahuan sebelum dan sesudah penyuluhan

\begin{tabular}{ccccc}
\hline No & Pengetahuan & Baik & Kurang & Jumlah \\
\hline 1. & Sebelum penyuluhan & 10 & 30 & \multirow{2}{*}{40} \\
2. & Sesudah penyuluhan & 28 & 12 & \\
\hline
\end{tabular}

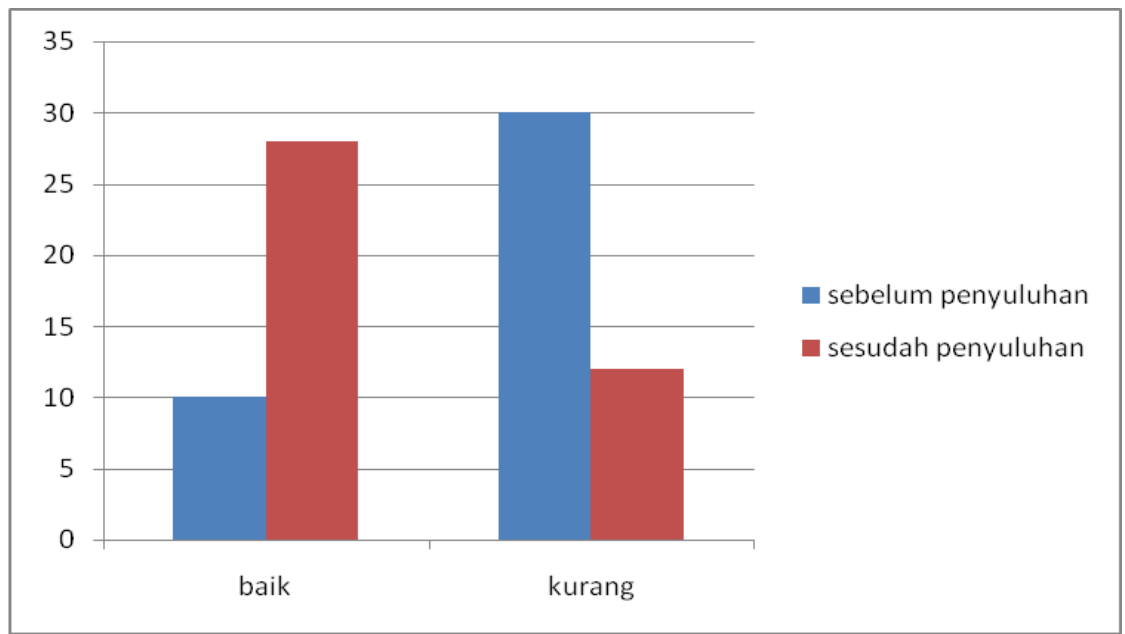

Gambar 3 Grafik peningkatan pengetahuan sebelum dan sesudah penyuluhan 


\section{SIMPULAN}

Pendidikan kesehatan yang dilakukan dengan cara penyuluhan adalah salah satu cara untuk memberikan informasi kepada masyarakat. Dengan diberikannya pengetahuan pendidikan kesehatan maka akan terbentuk perilaku hidup sehat oleh masyarakat. Tujuan dari pengabdian ini adalah pembentukan kelompok ibu siaga stunting dan meningkatkan pengetahuan ibu tentang pengertian stnting, dampak dan cara pencegahan stunting dan gizi buruk dengan program isi piringku sehingga secara langsung dapat membantu ibu dalam penurunan angka stunting dan gizi buruk serta bisa memberikan asupan pola makan dengan program isi piringku, pola asuh merawat balita, pemberian ASI Ekslusif, dan perilaku hidup bersih di Puskesmas Bumijawa Kabupaten Tegal.

\section{DAFTAR PUSTAKA}

Kemenkes RI, Edisi 02, 2018. Warta Kesmas Edisi 02 Tahun 2018 tentang Cegah stunting itu penting. Jakarta

$\begin{array}{lllll}\text { Kemenkes } & \text { RI, } & \text { Leaflet } & \text { isi } & \text { permas }\end{array}$ http://www.kesmas.kemkes.go.id/assets/upload/dir_519d41d8cd98f00/files/LEA FLET-ISI-PIRINGKU-ilovepdf-compressed_1011.pdf

Krisnansari. Nutrisi dan Gizi buruk. Mandala of Health. Volum 4 nomor 1. Januari 2010

Nora Rahmanindar, Nilatul Izah, Juhrotun Nisa (2019). Prosiding Seminar Nasional INAHCO 2019. Evaluasi Program Posyandu TFC (Theurapetic Feeding Center) sebagai Upaya Penanganan Balita Gizi Buruk di Puskesmas Bumijawa Kabupaten Tegal.

Doihttps://publikasi.polije.ac.id/index.php/inahco/article/view/1767/1109

Pedoman Pelayanan Anak Gizi Buruk. Kementerian Kesehatan Republik Indonesia, 2011

WHO, 2015.Global Database on Child Growth and Malnutrition 